Jurnal KBP

Volume 1 - No. 2, September 2013

\title{
ANALISIS KINERJA PERUSAHAAN PERBANKAN YANG TERDAFTAR DI BURSA EFEK INDONESIA (BEI)
}

\author{
Novi Yanti \\ STIE “KBP” Padang \\ (vie_pdg@yahoo.com)
}

\begin{abstract}
ABSTRAK
Penelitian ini dilakukan dengan tujuan untuk mengetahui perkembangan kinerja perusahaan perbankan yang terdaftar dibursa efek Indonesia (BEI), khususnya pada Bank Umum Milik Negara (BUMN) selama lima tahun berturut-turut, yaitu dari tahun 2007 sampai dengan tahun 2011. Jenis penelitian ini bersifat kuantitatif yaitu sumber data yang digunakan dari sumber eksternal dan merupakan data sekunder yang berasal dari ringkasan laporan keuangan yang dikeluarkan oleh Bursa Efek Indonesia (BEI). Teknik analisa data yang digunakan adalah teknik analisa rasio dengan metode horizontal yaitu dengan membandingkan laporan keuangan beberapa periode sehingga akan terlihat perkenbangan kinerja masing-masing bank tersebut.

Berdasarkan analisa rasio yang telah dilakukan tersebut yaitu ratio Permodalan, ratio likuiditas, dan ratio profitabilitas, maka hasilnya menunjukkan bahwa setiap bank itu berdeda-beda walaupun bank tersebut sama-sama Bank Umum Milik Negara (BUMN). Dimana untuk rasio permodalan kinerja ke empat bank tersebut yaitu Bank Mandiri (persero) Tbk, Bank BRI (persero) Tbk, Bank BTN (persero) Tbk, dan Bank BNI (persero) Tbk adalah baik (sehat) karna nilai yang dihasilkan melebihi ketetapan minimum bank yang sehat yaitu minimum $8 \%$. Untuk rasio likuiditas perkembangan kinerjanya ke empat bank tersebut yaitu Bank Mandiri (persero) Tbk, Bank BRI (persero) Tbk, Bank BTN (persero) Tbk, dan Bank BNI (persero) Tbk juga baik (sehat) yaitu tidak melebih ketetapan yang telah ditetapkan BI yaitu kecil dari 110\%, akan tetapi pada tahun 2011 kinerja Bank BRI kurang sehat karna nilai yang dihasilkan melebihi standar yang telah ditetapkan BI. Dan untuk rasio Profitabilitas perkembangan kinerja yang baik (sehat) diperolah oleh Bank Mandiri (persero) Tbk dan Bank BRI (persero) Tbk karena nilai ROA yang dihasilkan melebihi standar yang ditetapkan BI yaitu 1,5\% dan BOPO yang dihasilkan juga dibawah 93,5\% sebagaimana telah ditetapkan BI. Akan tetapi untuk Bank BTN (persero) Tbk tahun 2008 dan tahun 2009. Dan Bank BNI (persero) Tbk tahun 2007 dan 2008, untuk rasio ROA yang dihasilkannya kurang baik karena nilai yang dihasilkan kurang dari standar yang telah ditetapkan BI yaitu minimum 1,5\%.
\end{abstract}

\section{Kata Kunci: Kinerja keuangan, Perbankan, Bursa Efek Indonesia}

\section{PENDAHULUAN}

Dunia bisnis merupakan dunia yang paling ramai dibicarakan forum, baik yang bersifat nasional maupun internasional. Ramainya pembicaraan masalah ini disebabkan salah satu tolak ukur kemajuan suatu negara adalah dari kemajuan ekonominya dan tulang 
punggung dari kemajuan ekonomi adalah dunia bisnis.

Perusahaan yang bergerak dalam dunia bisnis terdiri dari beragam perusahaan dan bergerak dalam berbagai bidang usaha, mulai dari bidang usaha perdagangan, industri, pertanian, peternakan, perumahan, manufaktur, keuangan dan usaha-usaha lainnya. Semua bidang usaha tersebut tidak terlepas dari kebutuhan dana (modal) baik untuk modal investasi maupun modal kerja. Kebutuhan dana ini dipenuhi dari modal sendiri atau dari luar perusahaan. Dana dari luar bisa didapatkan dari lembaga-lembaga keuangan.

Menurut kasmir (2002:2) defenisi lembaga keuangan secara umum adalah setiap perusahaan yang bergerak dibidang keuangan, menghimpun dana, menyalurkan dana, atau kedua-duanya. Artinya kegiatan yang dilakukan oleh lembaga keuangan selalu berkaitan dengan bidang keuangan, apa kegiatannya menghimpun dana atau hanya menyalurkan dana atau kedua-duanya menghimpun dan menyalurkan dana, dan bisa juga disebut dengan jual beli uang.

Menurut kasmir (2002:29) dari kegiatan jual beli uang inilah bank akan memperoleh keuntungan yaitu dari selisih harga beli (bunga simpanan) dengan harga jual (bunga simpanan). Disamping itu kegiatan bank lainnya dalam rangka menghimpun dana dan menyalurkan dana adalah jasa-jasa lainnya. Kegiatan ini ditujukan untuk memperlancar kegiatan menghimpun dan menyalurkan dana, sehingga kita bisa melihat dan mengukur kinerja suatu perusahaan tersebut.

Kinerja perusahaan yang telah go publik akan sangat diperlukan dan bahkan diwajibkan untuk melaporkan kinerja perusahaannya secara periodik, termasuk dalam hal ini adalah perusahaan perbankan yang telah menjadi perusahaan publik dan terdaftar di Bursa Efek Indonesia (BEI).

Penilaian kinerja perusahaan penting dilakukan baik oleh manajemen, pemegang saham, pemerintah, dan pihak lain yang berkepentingan dan terkait dengan distribusi kesejahteraan diantara mereka, tidak terkecuali perusahaan perbankan, manajemen sangat memerlukan hasil pengukuran dan penilaian terhadap kinerja unit bisnisnya. Para investor sangat berkepentingan atas hasil pengukuran dan penilaian kinerja suatu badan usaha. Dengan mengetahui hasil pengukuran dan penilaian kinerja tersebut, maka mereka akan mampu untuk mengambil keputusan, apakah akan tetap bertahan sebagai pemilik badan usaha tersebut atau harus menjualnya kepada investor lain. Berapa tingkat keuntungan yang bisa dicapai dan bagaimana prospek usaha dimasa yang akan datang merupakan sebagian informasi penting bagi para investor yang maupun calon investor. Calon investor sangat berkepentingan terhadap kinerja suatu badan usaha untuk menentukan akan menjadi investor atau tidak dalam bidang usaha tersebut. Pemerintah sangat berkepentingan terhadap pengukuran dan penilaian kinerja suatu lembaga keuangan, sebab mempunyai fungsi yang strategis dalam rangka memajukan dan meningkatkan perekonomian Negara.

\section{TINJAUAN PUSTAKA DAN HIPOTESIS \\ Defenisi Pasar Modal}

Menurut Tandelilin (2001:25)

pasar modal secara umum dapat diartikan sebagai pasar yang 
memperjualbelikan produk berupa dana yang bersifat absrak, sedangkan dalam bentuk konkriknya, produk yang diperjual belikan di pasar modal berupa lembar surat-surat berharga efek.

Dalam pengertian klasik, pasar modal diartikan sebagai suatu bidang usaha perdagangan surat-surat berharga seperti saham, sertifikat saham, dan obligasi atau efek pada umumnya. Pasar modal dalam artian yang lebih operasional seperti yang tertuang dalam Kepres No. 60 tahun 1988, pasar modal di pahami sebagai bursa yang merupakan sarana yang mempertemukan penawaran permintaan dana jangka panjang (lebih dari satu tahun) dalam bentuk efek.

Pasar modal merupakan kegiatan yang berhubungan dengan penawaran umum dan perdangan efek, perusahaan publik yang berkaitan dengan efek yang diterbitkannya, serta lembaga dan propesi yang berkaitan dengan efek. Pasar modal menyediakan berbagai alternatif investasi bagi para investor selain alternatif investasi lainnya seperti: menabung di bank, membeli emas, asuransi, tanah dan bangunan, dan sebagainya. Pasar modal bertindak sebagai penghubung antara investor dengan perusahaan ataupun institusi pemerintah melalui perdagangan instrumen keuangan jangka panjang seperti obligasi, saham dan lainnya.

Menurut Tandelilin (2001:13) Pasar modal merupakan kegiatan yang mempertemukan antara pihak yang memiliki kelebihan dana (investor) dengan pihak yang membutuhkan dana (emiten) dengan cara memperjualbelikan sekuritas, yang memiliki umur lebih dari satu tahun, seperti saham dan obligasi. Sedangkan tempat terjadinya jual beli sekuritas disebut dengan bursa efek.
Pasar modal dapat mendorong terciptanya alokasi dana yang efesien, karena dengan adanya pasar modal maka pihak yang memiliki kelebihan dana (investor) dapat memilih alternatif investasi yang memberikan return yang paling optimal.

Menurut Tandelilin (2001: 18) instrument pasar modal adalah sebagai berikut:

a. Saham

Saham merupakan bukti kepemilikan atas asset-asset perusahaan yang menerbitkan saham. Saham merupakan salah satu jenis sekuritas yang popular yang diperjual belikan di pasar modal.

b. Obligasi (Bons)

Obligasi merupakan sekuritas yang memberikan pendapatan dalam jumlah tetap kepada pemiliknya. Pada saat membeli obligasi, investor sudah dapat mengetahui dengan pasti berapa pembayaran bunga yang akan diperolehnya secara periodik dan berapa pembayaran kembali nilai par (par value) pada saat jatuh tempo.

c. Reksadana

Reksadana (mutual fund) adalah sertifikat yang menjelaskan bahwa pemilik menitipkan sejumlah dana pada perusahaaan reksadana, untuk digunakan sebagai modal berinvestasi baik di pasar modal maupun di pasar uang.

d. Instrument Derivatif

Instrument deriviatif merupakan sekuritas yang nilainya merupakan turunan dari suatu sekuritas lain, sehingga instrument deriviatif sangat tergantung dari harga sekuritas lain yang ditetapkan sebagai patokan

\section{Pengertian dan Jenis Bank}

Menurut Kasmir (2010: 25) dalam pembicaraan sehari-hari, bank dikenal sebagai lembaga keuangan 
yang kegiatan utamanya menerima simpanan giro, tabungan, dan deposito. Kemudian bank juga dikenal sebagai tempat untuk meminjam uang (kredit) bagi masyarakat yang membutuhkannya.

Menurut UU No.10 tahun 1998 pengertian bank adalah badan usaha yang menghimpun dana dari masyarakat dalam bentuk simpanan dan menyalurkannya pada masyarakat dalam bentuk kredit dan bentuk lainnya dalam rangka meningkatkan taraf hidup rakyat.

Menurut undang-undang No 7 tahun 1992 tentang perbankan sebagaimana telah diubah dengan undang-undang No 10 tahun 1998 pengertian bank adalah badan usaha yang menghimpun dana dari masyarakat dalam bentuk simpanan dan menyalurkannya kepada masyarakat dalam bentuk kredit dan atau bentukbentuk lainnya dalam rangka meningkatkan taraf hidup rakyat banyak.

Menurut Stuart seperti dikutip oleh Suyatno (2003: 1) bank adalah suatu badan yang bertujuan untuk memuaskan kredit, baik dengan alat pembayaran sendiri atau dengan uang yang diperolehnya dari orang lain, maupun dengan jalan memperedarkan alat-alat penukar baru yang berupa uang giral.

Pengertian diatas memiliki kandungan filosofi yang tinggi. Pengertian yang teknis dapat ditemukan pada Standar Akuntansi Keuangan (PSAK) dan Surat Keputusan Mentri Keuangan RI No 792 tahun1990. Pengertian bank menurut PSAK No 31 dalam Standar Akuntansi Keuangan (1990:31:1) adalah suatu lembaga yang berperan sebagai perantara keuangan antara pihak-pihak yang memiliki kelebihan dana dan pihak-pihak yang memerlukan dana, serta sebagai lembaga yang berfungsi memperlancar lalu lintas pembayaran.

Menurut kasmir (2004:18) peredaran lainnya adalah dilihat dari segi siapa nasabah yang mereka layani, apakah masyarakat dalam lokasi tertentu. Jenis perbankan juga dibagi ke dalam caranya menentukan harga jual dan harga beli.

Jika dilihat dari jenis-jenis, bank dapat dilihat dari segi kepemilikannya yaitu:

a. Bank Milik Pemerintah

Dimana baik akte pendirian maupun modalnya dimiliki oleh pemerintah, sehingga seluruh keuntungan bank ini dimiliki oleh pemerintah pula.

b. Bank Milik Swasta Nasional

Bank jenis ini sebagian besar dimilki oleh swasta nasional serta akte pendieiannya didirikan oleh swasta, begitu pula pembagian keuntungannya untuk keuntungan swasta pula.

c. Bank Milik Koperasi

Kepemilikan saham-saham bank ini dimiliki oleh perusahaan yang berbadan hukum koperasi.

d. Bank Milik asing

Bank jenis ini merupakan cabang dari bank yang ada diluar negri, baik milik swasta maupun milik pemerintah asing. Jenis kepemilikannyapun dimiliki oleh pihak luar negri.

e. Bank Milik Campuran

Kepemilikan saham bank campuran dimiliki oleh pihak asing dan pihak swasta nasional. Kepemilikan sahamnya secara mayoritas dipegang oleh warga Negara Indonesia.

Setelah keluar UU Pokok perbankan No. 7 tahun1992 dan ditegaskan lagi dengan keluarnya Undang-undang RI no. 10 tahun 1998 maka jenis perbankan terdiri dari: 
a. Bank Umum

Bank umum adalah bank yang melaksanakan kegiatan usaha secara konvensional dan atau berdasarkan prinsip syariah yang dalam kegiatannya memberikan jasa dalam lalu lintas pembayaran. Sifat jasa yang diberikan adalah umum dalam artian dapat memberikan seluruh jasa perbankan yang ada. Begitu pula dengan wilayah operasinya dapat dilakukan seluruh wilayah. Bank umum sering disebut Bank konvensional.

b. Bank Perkreditan Rakyat

Bank pengkreditan rakyat adalah bank yang melaksanakan usaha secara konvensional atau berdasar prinsip syariah yang dalam kegiatannya tidak memberikan jasa dalam lalu lintas pembayaran. Artinya disini kegiatan bank pengkreditan rakyat jauh lebih sempit jika dibandingkan dengan kegiatan Bank Umum.

\section{Kinerja Keuangan}

Menurut Singgih (2000:1)
Sebagai wujud yang dicapai perusahaaan dalam periode waktu usaha, tidak terlepas dari kinerja yang dilakukan pihak perusahaan. Apabila kinerja perusahaan bagus, akan menghasilkan prestasi yang bagus pula, begitu juga sebaliknya. Menurut mentri keuangan RI berdasarkan keputusan No. 740/KMK.00/1989 tanggal 28 juni 1989, bahwa yang dimaksud dengan kinerja keuangan adalah prestasi yang dicapai oleh perusahaan dalam periode tertentu yang mencerminkan tingkat kesehatan dari perusahaan tersebut.

Menurut PSAK (1996) kinerja perusahaan dapat diukur dengan menganalisa dan mengevaluasi laporan keuangan. Informasi posisi keuangan dan kinerja keuangan dimasa lalu seringkali digunakan sebagai dasar untuk memprediksi posisi keuangan dimasa depan dan hal-hal lain yang langsung menarik perhatian pemakaian seperti pembayaran dividen, upah, pergerakan harga sekuritas dan kemampuan perusahaan untuk memenuhi komitmennya ketika jatuh tempo.

Kinerja merupakan hal penting yang harus dicapai oleh setiap perusahaan, karena kinerja merupakn cerminan dari kemampuan perusahaan dalam mengelola dan mengalokasikan sumber dananya. Selain itu, tujuan pokok penilaian kinerja adalah untuk memotivasi karyawan dalam mencapai sasaran organisasi dan dalam mematuhi standar prilaku yang telah ditetapkan sebelumnya, agar membuahkan tindakan dan hasil yang diharapkan. Standar prilaku dapat berupa kebijakan manajemen atau rencana formal yang dituangkan dalam anggaran.

\section{Laporan keuangan}

Menurut Munawir (2002:5) laporan keuangan pada dasarnya adalah hasil dari proses akuntansi yang dapat digunakan sebagai alat untuk berkomunikasi antarandata keuangan atau aktivitas suatu perusahaan dengan pihak-pihak yang berkepentingan dengan data atau aktivitas perusahaan tersebut.

PSAK No. 1 tahun 2002 menyatakan bahwa laporan keuangan menunjukkan apa yang telah dilakukan manajemen atas pertanggungjawaban manajemen atas sumber daya yang dipercayakan kepadanya. Pemakaian laporan keuangan terdiri dari investor sekarang dan investor potensial, karyawan, pemberi pinjaman, pemasok dan kreditur usaha lain, pelanggan, pemerintah dan masyarakat yang menggunakan untuk membantu dalam menentukan apakah harus membeli, menahan atau menjual investasinya. 
Menurut PSAK No 1 revisi 2009 menyebutkan laporan keuangan adalah suatu penyajian terstruktur dari posisi keuangan dan kinerja keuangan suatu entitas. Tujuan laporan keuangan adalah memberikan informasi mengenai posisi keuangan, kinerja keuangan, dan arus kas entitas yang bermanfaat bagi sebagian besar kalangan pengguna laporan keuangan dalam pembuatan keputusan ekonomi. Laporan keuangan juga menunjukkan hasil pertanggung-jawaban manajemen atas penggunaan sumber daya yang dipercayakan kepada mereka.

Menurut Skousen, Stice dan Stice tahun 2000 (dalam mulyani dan meiden: 2003) menyatakan bahwa yang dimaksud dengan laporan keuangan meliputi Statement of Financial Position, Statement of Earning and Comrehensive Income, Statement of Cas Flow dan Statement of Investment by and Distribution to Owners. Laporan keuangan tersebut berisi informasi akuntansi yang digunakan oleh pengguna eksternal sebagai dasar dalam pengambilan keputusan ekonomi.

Laporan keuangan yang disajikan oleh bank Umum untuk dipublikasikan kepada masyarakat, berpedoman pada Peraturan bank Indonesia No. 3/22/PBI tanggal 13 Desember 2001 tentang Transparansi kondisi keuangan Bank dan Surat Edaran Bank Indonesia No. 3/30/DPNP tanggal 14 desember 2001 tentang laporan keuangan Publikasi Triliwunan dan Bulanan bank Umum serta laporan tertentu yang disampaikan kepada Bank Indonesia. Laporan keuangan bank umum ini terdiri sebagai berikut:
a. Neraca
b. Perhitungan laba
c. Komitmen dan kontijensi
d. Perhitungan Kewajiban Penyedian Modal Minimum

e. Kualitas aktiva produktif dan informasi lainnya

f. Transaksi valuta asing dan derivative

g. Perhitungan rasio keuangan

h. Pembelian kredit dari Badan Penyehatan Perbankan Nasional/ BPPN (jika ada)

\section{Analisa rasio keuangan perbankan}

\section{Analisa Rasio Permodalan}

Menurut Mudrajad Kuncoro dan

Suhardjono (2002:562) CAR adalah kemampuan bank dalam mempertahamkan modal yang mencukupi dan kemampuan manajemen bank dalam mengidentifikasi, mengukur, mengawasi dan mengontrol risikorisiko yang timbul yang dapat berpengaruh trhadap besarnya modal bank.

CAR adalah rasio yang memperlihatkan seberapa jauh seluruh aktiva bank yang mengandung resiko (kredit, penyertaan, surat berharga, tagihan pada bank lain) ikut dibiayai dari dana modal sendiri bank di samping memperoleh dana-dana dari sumber-sumber di luar bank, seperti dana masyarakat, pinjaman (utang), dan lain-lain. Dengan kata lain, CAR adalah rasio kinerja bank untuk mengukur kecukupan modal yang dimilki bank untuk menunjang aktiva yang mengandung atau menghasilkan resiko, misalnya kredit yang diberikan. CAR merupakan indicator terhadap kemampuan bank untuk menutupi penurunan aktivanya sebagai akibat dari kerugian-kerugian bank yang disebabkan oleh aktiva yang beresiko. Semakin tinggi CAR maka semakin baik kemampuan bank tersebut untuk menanggung risiko dari setiap kredit atau aktiva produktif yang beresiko.

Besarnya CAR diukur dari rasio antara modal bank terhadap Aktiva 
Tertimbang Menurut Risiko (ATMR). Menurut ketetapan Bank Indonesia Nomor: 6/10/PBI/2004. Sebuah bank mengalami risiko modal apabila tidak dapat menyediakan modal minimum sebesar $8 \%$. Dengan penetapan CAR pada tingklat tertentu dimaksudkan agar bank memiliki kemampuan modal yang cukup untuk meredam kemungkinan timbulnya risiko sebagai akibat ber-kembang atau meningkatnya ekspansi asset terutama aktiva yang di kategorikan dapat memberikan hasil sekaligus mengandung resiko.

Menurut Lukman Dendawijaya (2009:144), besarnya CAR suatu bank dapat dihitung dengan rumus berikut.

$$
C A R=\frac{\text { Modal }}{\text { ATMR }} \times 100 \%
$$

\section{Analisis Rasio Likuiditas}

Menurut G Sugiarso dan F. Winarni (2005:114) analisis rasio likuiditas adalah analisis yang dilakukan terhadap kemampuan bank dalam memenuhi kewajiban-kewajiban jangka pendeknya atau kewajiban yang sudah jatuh tempo. Likuiditas dibedakan menjadi dua, yaitu likuiditas badan usaha dan likuiditas perusahaan. Likuiditas badan usaha merupakan kemampuan perusahaan menyediakan alat-alat likuid sedemikian rupa sehingga dapat memenuhi kewajiban finansialnya pada saaat ditagih. Sementara itu likuiditas perusdahaan merupakan kemampuan perusahaan menyediakan alat-alat likuid sedemikian rupa sehingga perusahaan mampu menyelenggarakan proses produksi. Rasio likuiditas yang digunakan dalam menilai kinerja suatu bank adalah: Loan to Deposit Ratio (LDR)

Menurut G Sugiarso dan F. Winarni (2005:117) Loan to Deposit ratio adalah seluruh jumlah kredit yang diberikan bank dengan dana yang diterima oleh bank. Rasio ini menunjukkan salah satu penilaian likuiditas bank.

Menurut Lukman Dendawijaya (2009: 116) LDR adalah rasio antara seluruh kredit yang diberikan bank dengan dana yang diterima oleh bank. Menurut Veithzal Rivai (2006:156) LDR menyatakan seberapa jauh kemampuan bank dalam membayar kembali penarikan dana yang dilakukan masyarakat dengan mengandalkan kredit yang diberikan sebagai sumber likuiditasnya. artinya seberapa jauh pemberian kredit kepada nasabah kredit dapat mengimbangi kewajiban bank untuk dapat segera memenuhi permintaan deposan yang ingin menarik kembali dananya yang telah digunakan oleh bank untuk memberikan kredit.

LDR disebut juga rasio kredit terhadap total dana pihak ketiga yang digunakan untuk mengukur dana pihak ketiga yang disalurkan dalam bentuk kredit. Penyaluran kredit merupakan kegiatan utama bank, oleh karena itu sumber pendapatan bank berasal dari kegiatan ini. Semakin besar penyaluran dana dalam bentuk kredit dibandingkan dengan deposit atau simpanan masyarakat pada suatu bank membawa konsekuensi semakin besarnya resiko yang harus ditanggung oleh bank yang bersangkutan. Menurut Kasmir (2008: 290), rasio LDR merupakan rasio untuk mengukur komposisi jumlah kredit yang diberikan dibandingkan dengan jumlah dana masyarakat dan modal sendiri yang digunakan.

Jika total kredit yang diberikan lebih besar daripada jumlah dana yang dihimpun maka akan mengindikasikan bahwa semakin rendahnya kemampuan likuiditas bank tersebut. Halini disebabkan karena jumlah dana yang diperlukan untuk membiayai kredit menjadi semakin besar. Dan begitu 
pula sebaliknya, apabila jumlah kredit yang diberikan lebih kecil daripada jumlah dana yang dihimpun maka akan terjadi penumpukan dana yang tidak produktif pada bank tersebut yang pada hakikatnya merupakan alat likuid yang sebagian basar berupa kas, berasal dari penghimpunan dana masyarakat yang didalamnya terdapat unsure biaya bunga.

Menurut ketetapan Bank Indonesia Nomor: 6/10/PBI/2004. Tata cara dalam penilaian tingkat kesehatan bank untuk LDR adalah sebagai berikut:

a. Untuk rasio LDR sebesar $110 \%$ atau lebih diberikan nilai kredit 0 , artinya likuiditas bank tersebut dinilai tidak sehat.

b. Untuk rasio LDR dibawah $110 \%$ diberi nilai kredit 100 , artinya bank tersebut dinilai sehat

Rasio ini juga merupakan indikator kerawanan dan kemampuan dari suatu bank. Sebagai praktisi perbankan menyepakati bahwa batas aman dari loan to deposit ratio sesuatu bank adalah sekitar $80 \%$, namun, batas toleransi berkisar antara $85 \%-100 \%$. Besarnya LDR menurut peraturan pemerintah maksimum adalah $110 \%$. Sesuai SE No.6/23/DPNP tanggal 31 Mei 2004 LDR dapat dirumuskan sebagai berikut.

$\begin{aligned} & L D R= \frac{\text { kredit }}{\text { dana pihak ketiga }} \times 100 \% \\ & \text { Kredit merupakan total kredit }\end{aligned}$ yang diberikan kepada pihak ketiga (tidak termasuk antar bank). Dana pihak ketiga mencakup giro, tabungan, dan depositi (tidak termasuk antar bank).

\section{Analisis Rasio Profitabilitas}

Rasio profitabilitas atau Operating Rasio menggambarkan kemampuan perusahaan mendapatkan laba melalui semua kemampuan, dan sumber yang ada seperti kegiatan penjualan, kas, modal, jumlah karyawan, jumlah cabang, dan sebagainya. Rasio ini mengikur efektifitas pimpinan dalam mengelola perusahaan,yang tercermin dalam laba yang diperoleh dari penjualan.

Rasio profitabilitas yang

digunakan adalah:

a. Return on Asset (ROA)

Menurut Lukman Dendawijaya (2009: 119), Dalam penentuan tingkat kesehatan suatu bank, Bank Indonesia lebih mementingkan penilaian besarnya ROA karena Bank Indonesia sebagai Pembina dan pengawas perbankan lebih mengutamakan nilai profitabilitas suatu bank yang diukur dengan asset yang dananya sebagian besar berasal dari dana simpanan masyarakat. Menurut ketetapan Bank Indonesia Nomor: 6/10/PBI/2004, suatu bank dapat dimasukkan dalam kategori sehat apabila memiliki rasio ROA minimal $1,5 \%$.

ROA digunakan untuk mengukur efektifitas perusahaan di dalam menghasilkan keuntungan dengan memanfaatkan aktiva atau asset yang dimiliki. Dengan kata lain, rasio ini digunakan untuk mengukur kemampuan manajemen bank dalam memperoleh keuntungan (laba) secara keseluruhan. Semakin besar ROA suatu bank, semakin besar pula tingkat keuntungan yang dicapai bank tersebut dan semakin baik pula posisi bank tersebut dari segi penggunaan asset.

Menurut Lukman Dendawijaya (2009: 118) ROA dapat dirumuskan sebagai berikut.

$R O A=\frac{\text { Laba sebelum pajak }}{\text { Total aktiva }} \times 100 \%$

b. Rasio Beban Operasional terhadap Pendapatan Operasional (BOPO) 
Rasio ini digunakan untuk mengukur tingkat efesiensi dan kemampuan bank dalam melakukan kegiatan operasinya, terutama kredit. Menurut Lukman Dendawijaya (2009: 120), mengingat kegiatan utama bank pada prinsipnya adalah bertindak sebagai perantara, yaitu menghimpun dan menyalurkan dana (misalnya dana masyarakat), maka biaya dan pendapatan operasional bank didominasi oleh biaya bunga dan pendapatan bunga.

Menurut Lukman Dendawijaya (2009: 111), biaya operasional merupakan biaya yang dikeluarkan oleh bank dalam rangka menjalankan aktifitas usaha pokoknya. Biaya operasional terdiri dari biaya bunga, biaya valuta asing lainnya, biaya tenaga kerja, biaya pemasaran, biaya penyusutan, dan biaya operasional lainnya. Pendapatan operasional terdiri atas semua pendapatan yang merupakan hasil langsung dari kegiatan usaha bank yang benar-benar telah diterima. Pendapatan operasional bank terdiri atas hasil bunga, provisi dan komisi, pendapatan valuta asing lainnya, dan pendapatan operasional lainnya.

Semakin kecil BOPO menunjukkan semakin efesien bank dalam menjalankan aktivitas usahanya. Menurut ketetapan Bank Indonesia Nomor: 6/10/PBI/2004, suatu bank dapat dimasukkan dalam kategori sehat apabila memiliki rasio BOPO tidak melebihi 93,5\%.

Menurut Lukman dendawijaya (2009: 119), secara sistematik BOPO dapat dirumuskan sebagai berikut.

$$
\begin{aligned}
& \text { BOPO } \\
& =\frac{\text { Beban Operasional }}{\text { Pendapatan operasional }} \times 100 \%
\end{aligned}
$$

\section{Pengertian dan Tujuan Analisis Laporan Keuangan}

Menurut Hery (2009: 6) laporan keuangan pada dasarnya adalah hasil dari proses akuntansi yang dapat digunakan sebagai alat untuk mengomunikasikan data keuangan atau aktivitas perusahaan kepada pihakpihak yang berkepentingan. Dengan kata lain, laporan keuangan ini berfungsi sebagai alat informasi yang menghubungkan perusahaan dengan pihak-pihak yang berkepentingan, yang menunjukkan kondisi kesehatan keuangan perusahaan dan kinerja perusahaan.

Tujuan khusus laporan keuangan menurut APB Statement No. 4 adalah menyajikan posisi keuangan, hasil usaha, dan perubahan posisi keuangan lainnya secara wajar dan sesuai dengan prinsip-prinsip akuntansi yang berlaku umun (GAAP), sedangkan laporan umum laporan keuangan menurut APB Statement No.4 adalah:

a. Memberikan informasi yang terpercaya tentang sumber daya ekonomi dan kewajiban perusahaan,

b. Memberikan informasi yang terpercaya tentang sumber kekayaan bersih yang berasal dari kegiatan usaha dan mencari laba,

c. Memungkinkan untuk menaksir potensi perusahaan dalam menghasilkan laba,

d. Memberikan informasi yang diperlukan lainnya tentang perubahan aktiva dan kewajiban, dan

e. Mengungkapkan informasi relevan lainnya yang dibutuhkan para pemakai laporan.

Pernyataan Standar Akuntansi Keuangan (PSAK) No. 1 menjelaskan bahwa tujuan laporan keuangan adalah menyediakan informasi yang menyangkut posisi keuangan, kinerja, 
beserta perubahan posisi keuangan suatu perusahaan yang bermanfaat bagi sejumlah besar pemakai dalam pengambilan keputusan.

Urutan laporan keuangan berdasarkan proses penyajian adalah:
a. Laporan laba rugi (Income Statemant)
b. Laporan Modal Pemilik (Statement of Owner's Equity)
c. Neraca (Balance Sheet)
d. Laporan Arus Kas (Statement of Cash Flows)
Dalam analisis perbandingan laporan keuangan yang dibandingkan adalah laporan keuangan dari beberapa saat atau periode pada satu perusahaan dan laporan keuangan dari satu periode antara dua perusahaan yang sejenis. Tujuan analisis ini adalah untuk mengetahui perubahan-perubahan yang terjadi dalam laporan keuangan, dan untuk meneliti lebih lanjut perubahanperubahan yang terjadi agar informasi akibat dari perubahan tersebut.

Hal-hal yang menyebabkan perubahan-perubahan dalam laporan keuangan adalah:
a. Laba atau rugi yang bersifat operasional ataupun insidentil
b. Adanya aktiva baru,atau perubahan bentuk aktiva
c. Timbul atau luasnya utang atau perubahan utang yang satu ke utang yang lainnya
d. Bertambah atau kurangnya modal saham

\section{METODE PENELITIAN \\ Objek Penelitian}

Adapun yang menjadi objek penelitian ini adalah beberapa perusahaan perbankan yang listed di Bursa Efek Indonesia (BEI).

\section{Populasi dan Sampel}

Menurut Sugiyono (2006)

populasi adalah merupakan wilayah generalisasi yang terdiri dari atas objek atau subjek yang mempunyai kualitas dan karakteristik tertentu yang ditetapkan oleh peneliti untuk dipelajari dan ditarik kesimpulannya.

Menurut Sugiyono (2006) sampel adalah bagian dari jumlah yang karakteristik yang dimiliki oleh populasi tersebut.

Populasi yang dipilih dalam penelitian ini adalah perusahaan perbankan yang telah go publik. Sampel dipilih berdasarkan metode purposive Sampling yaitu metode yang berdasarkan pada diri atau sifat-sifat tertentu. Yakni perusahaan perbankan yang akan dijadikan sampel dalam penelitian ini dipilih dengan menggunakan pertimbangan dengan memasukkan unsur-unsur tertentu yang dianggap memiliki kriteria sebagai berikut:

a. Perusahaan yang terdaftar di Bursa Efek Indonesia (BEI) yang telah menyampaikan laporan keuangan per 31 desember 2007, 31 desember 2008, 31 desember 2009, 31 desember 2010 dan per 31 desember 2011.

b. Perusahaan yang terdaftar di Bursa Efek Indonesia (BEI) yang menyampaikan data secara lengkap sesuai dengan informasi yang diperlukan, yakni Rasio Likuiditas, Rasio Probabilitas dan Rasio Leverage.

c. Perusahaan yang terdaftar di Bursa Efek Indonesia (BEI) yang merupakan perusahaan perbankan yang Persero Tbk, dimana perusahaan ini merupakan Bank Umum Milik Negara.

Berikut nama-nama perusahaan yang menjadi sampel dalam penelitian ini adalah sebagai berikut:

a. PT. Bank Mandiri (Persero) Tbk.

b. PT. Bank Rakyat Indonesia (Persero) Tbk. 
c. PT. Bank Tabungan Negara (Persero) Tbk.

d. PT. Bank Negara Indonesia (Persero) Tbk.

\section{Jenis dan Sumber Data}

Jenis data dalam penelitian ini adalah data sekunder. Data sekunder adalah data yang diperoleh peneliti melalui perantara media yang berasal dari ringkasan laporan keuangan yang dikeluarkan oleh Bursa Efek Indonesi (BEI) yang diumumkan secara online pada internet dengan situs httpllwww.bei.co.id. Sumber data berasal dari laporan keuangan akhir tahun yang diumumkan secara online pada internet.

\section{Teknik Analisa Data}

Teknik analisa data yang digunakan adalah teknik analisa rasio. Dengan metode horizontal yaitu dengan membandingkan laporan keuangan beberapa periode sehingga akan terlihat perkembangan masingmasing bank tersebut.

\section{HASIL DAN PEMBAHASAN \\ PT. Bank Mandiri (Persero) Tbk.}

Bank Mandiri berdiri pada tanggal 2 oktober 1998 sebagai bagian dari program restrukturisasi perbankan yang dilaksanakan oleh pemerintah Indonesia. Pada bulan juli 1999, empat bank milik pemerintah yaitu Bank Dagang Negara, bank Bumi Daya, Bank Ekspor Impor Indonesiabdan Bank Pembangunan Indonesia, bergabung menjadi Bank Mandiri. Keempat bank tersebut telah turut membentuk riwayat perkembangan perbankan di Indonesia dimana sejarahnya berawal pada lebih dari 140 tahun yang lalu.

Pada saat ini, berkat kerja keras lebih dari 21.000 karyawan yang tersebar di 909 kantor cabang dan didukung oleh anak perusahaan yang bergerak dibidang investment banking, perbankan syariah serta bancassurance, Bank Mandiri menyediakan solusi keuangan yang menyeluruh bagi perusahaan swasta maupun milik Negara, komersil, usaha kecil dan mikro serta nasabah konsumen.

Pada tanggal 14 juli 2003, Pemerintah Indonesia melakukan divestasi sebesar 20\% atas kepemilikan saham di Bank Mandiri melalui penawaran umum perdana, (IPO). Selanjutnya pada tanggal 11 Maret 2004, Pemerintah Republik Indonesia melalui divestasi lanjutan atas $10 \%$ kepemilikan di Bank Mandiri.

1) Visi Bank Mandiri

Bank terpercaya pilihan anda

2) Misi Bank Mandiri

a. Berorientasi pada pemenuhan kebutuhan pasar

b. Mengembangkan sumberdaya manusia professional

c. Memberi keuntungan yang maksimal bagi stakeholder

d. Melaksanakan manajemen terbuka

e. Peduli terhadap kepentingan masyarakat dan lingkungan

\section{PT. Bank Rakyat Indonesia (Persero)} Tbk.

Bank Rakyat Indonesia (BRI) adalah salah satu bank milik pemerintah yang terbesar di Indonesia. Pada awalnya Bank Rakyat Indonesia (BRI) didirikan di Purwokerto, Jawa Tengah oleh Raden Bei Aria Wirjaatmadja dengan nama De Poerwokertosche Hulp en Spaarbank der Inlandsche Hoofden atau "Bank Bantuan dan Simpanan Milik Kaum Priyayi Purwokerto", suatu lembaga keuangan yang melayani orang-orang berkebangsaan Indonesia (pribumi). Lembaga tersebut berdiri tanggal 16 Desember 1895, yang kemudian dijadikan sebagai hari kelahiran BRI 
Pada periode setelah kemerdekaan RI, berdasarkan Peraturan Pemerintah No. 1 tahun 1946 Pasal 1 disebutkan bahwa BRI adalah sebagai Bank Pemerintah pertama di Republik Indonesia. Dalam masa perang mempertahankan kemerdekaan pada tahun 1948, kegiatan BRI sempat terhenti untuk sementara waktu dan baru mulai aktif kembali setelah perjanjian Renville pada tahun 1949 dengan berubah nama menjadi Bank Rakyat Indonesia Serikat. Pada waktu itu melalui PERPU No. 41 tahun 1960 dibentuklah Bank Koperasi Tani dan Nelayan (BKTN) yang merupakan peleburan dari BRI, Bank Tani Nelayan dan Nederlandsche Maatschappij (NHM). Kemudian berdasarkan Penetapan Presiden (Penpres) No. 9 tahun 1965, BKTN diintegrasikan ke dalam Bank Indonesia dengan nama Bank Indonesia Urusan Koperasi Tani dan Nelayan.

Setelah berjalan selama satu bulan, keluar Penpres No. 17 tahun 1965 tentang pembentukan bank tunggal dengan nama Bank Negara Indonesia. Dalam ketentuan baru itu, Bank Indonesia Urusan Koperasi, Tani dan Nelayan (eks BKTN) diintegrasikan dengan nama Bank Negara Indonesia unit II bidang Rural, sedangkan NHM menjadi Bank Negara Indonesia unit II bidang Ekspor Impor (Exim).

Berdasarkan Undang-Undang No. 14 tahun 1967 tentang Undangundang Pokok Perbankan dan Undangundang No. 13 tahun 1968 tentang Undang-undang Bank Sentral, yang intinya mengembalikan fungsi Bank Indonesia sebagai Bank Sentral dan Bank Negara Indonesia Unit II Bidang Rular dan Ekspor Impor dipisahkan masing-masing menjadi dua Bank yaitu Bank Rakyat Indonesia dan Bank Ekspor Impor Indonesia. Selanjutnya berdasarkan Undang-undang No. 21 tahun 1968 menetapkan kembali tugastugas pokok BRI sebagai bank umum.

$$
\text { Sejak } 1 \text { Agustus } 1992
$$

berdasarkan Undang-Undang

Perbankan No. 7 tahun 1992 dan Peraturan Pemerintah RI No. 21 tahun 1992 status BRI berubah menjadi perseroan terbatas. Kepemilikan BRI saat itu masih $100 \%$ di tangan Pemerintah Republik Indonesia. Pada tahun 2003, Pemerintah Indonesia memutuskan untuk menjual 30\% saham bank ini, sehingga menjadi perusahaan publik dengan nama resmi PT. Bank Rakyat Indonesia (Persero) Tbk., yang masih digunakan sampai dengan saat ini.

1) Visi Bank Rakyat Indonesia

Menjadi bank komersial terkemuka yang selalu mengutamakan kepuasan nasabah.

2) MIsi Bank Rakyat Indonesia

a. Melakukan kegiatan perbankan yang terbaik dengan mengutamakan pelayanan kepada usaha mikro, kecil dan menengah untuk menunjang peningkatan ekonomi masyarakat.

b. Memberikan pelayanan prima kepada nasabah melalui jaringan kerja yang tersebar luas dan didukung oleh sumber daya manusia yang profesional dengan melaksanakan praktek good corporate governance.

c. Memberikan keuntungan dan manfaat yang optimal kepada pihak-pihak yang berkepentingan.

\section{PT. Bank Tabungan Negara (Persero) Tbk.}

Bank Tabungan Negara atau BTN adalah Badan Usaha Milik Negara Indonesia yang berbentuk perseroan terbatas dan bergerak di bidang jasa keuangan perbankan. BTN dimulai dengan didirikannya 
Postspaarbank di Batavia pada tahun 1897. Pada tahun 1942, pada masa pendudukan Jepang di Indonesia, bank ini dibekukan dan digantikan dengan Tyokin Kyoku. Setelah proklamasi kemerdekaan Indonesia bank ini diambil alih oleh pemerintah Indonesia dan diubah menjadi Kantor Tabungan Pos. Nama dan bentuk perusahaan selanjutnya berubah beberapa kali hingga akhirnya pada tahun 1998 diubah menjadi nama dan bentuk resmi yang berlaku saat ini.

1) Visi Bank Tabungan Negara

Menjadi bank yang terkemuka dalam pembiayaan perumahan

2) Misi Bank Tabungan Negara

a. Memberikan pelayanan unggul dalam pembiayaan perumahan dan industri terkait, pembiayaan konsumsi dan usaha kecil menengah.

b. Meningkatkan keunggulan kompetitif melalui inovasi pengembangan produk, jasa dan jaringan strategis berbasis teknologi terkini.

c. Menyiapkan dan mengembangkan Human Capital yang berkualitas, profesional dan memiliki integritas tinggi.

d. Melaksanakan manajemen perbankan yang sesuai dengan prinsip kehati-hatian dan good corporate governance untuk meningkatkan Shareholder Value

e. Mempedulikan kepentingan masyarakat dan lingkungannya.

\section{PT. Bank Negara Indonesia (Persero) Tbk.}

Berdiri sejak 1946, BNI yang dahulu di kenal sebagai Bank Negara Indonesia, merupakan bank pertama yang didirikan dan dimiliki oleh pemerintah Indonesia. Bank Negara Indonesia mulai mengedarkan alat pembayaran resmi pertama yang dikeluarkan pemerintah Indonesia, yakni ORI atau Oeang Republik Indonesia, pada malam menjelang tanggal 30 Oktober 1946, hanya beberapa bulan sejak pembentukannya hingga kini, tanggal tersebut di peringati sebagai Hari Keuangan Nasional.

Menyusul penunjukkan De Javache Bank yang merupakan warisan dari pemerintah Belanda sebagai bank sentral pada tahun 1949, pemerintah membatasi peranan Bank Negara Indonesia sebagai bank sirkulasi atau bank sentral. Bank Negara Indonesia lalu ditetapkan sebagai bank pembangunan, dan kemudian diberi hak untuk bertindak sebagai bank devisa, dengan akses langsung untuk transaksi luar negeri.

Sehubungan dengan penambahan modal pada tahun 1955, status Bank Negara Indonesia di ubah menjadi bank komersial milik pemerintah. Perusahaan ini melandasi pelayanan yang lebih baik dan luas bagi sector usaha nasional. Sesuai dengan keputusan penggunaan tahun pendirian sebagai bagian dari identitas perusahaan, nama Bank Negara Indonesia 1946 resmi digunakan mulai akhir 1968.

Tahun 1992, status hukum dan nama BNI berubah menjadi PT. Bank Negara Indonesia (Persero) Tbk , semetara keputusan untuk menjadi perusahaan publik diwujudkan melalui penawaran saham perdana di pasar modal pada tahun 1996.

Kemampuan BNI untuk beradaptasi terhadap perubahan dan kemajuan lingkungan social budaya serta teknologi di cerminkan melalui penyempurnaan identitas perusahaan yang berkelanjutan dari masa ke masa. Hal ini juga menegaskan dedikasi dan komitmen BNI terhadap perbankan kualitas kinerja secara terus menerus. 


\section{1) Visi BNI}

Menjadi Bank kebanggaan nasional yang Unggul, Terkemuka dan Terdepan dalam Layanan dan Kinerja

2) Misi BNI

a. Memberikan layanan prima dan solusi yang bernilai tambah kepada seluruh nasabah, dan selaku mitra pillihan utama (the bank choice)

b. Meningkatkan nilai investasi yang unggul bagi investor.

c. Menciptakan kondisi terbaik sebagai tempat kebanggaan untuk berkarya dan berprestasi.

d. Meningkatkan kepedulian dan tanggung jawab terhadap lingkungan sosial. e. Menjadi acuan pelaksanaan kepatuhan dan tata kelola perusahaan yang baik.

Analisis Perkembangan Kinerja Perusahaan Perbankan Tahun 2007 sampai dengan Tahun 2011

a. Analisis Perkembangan Kinerja Bank Mandiri tahun 2007 sampai dengan Tahun 2011

Perkembangan kinerja Bank Mandiri (Persero) Tbk yang dilihat dengan menggunakan rasio permodalan, rasio likuiditas, dan rasio profitabilitas. Untuk lebih jelas dapat dilihat pada table 4.2.1 dibawah ini:

Tabel 1

Analisis Kinerja Keuangan Bank Mandiri Tahun 2007 sampai dengan 2011( \%)

\begin{tabular}{|l|c|c|c|c|c|}
\hline KETERANGAN & $\mathbf{2 0 0 7}$ & $\mathbf{2 0 0 8}$ & $\mathbf{2 0 0 9}$ & $\mathbf{2 0 1 0}$ & $\mathbf{2 0 1 1}$ \\
\hline $\begin{array}{l}\text { 1. Ratio Permodalan (CAR) } \\
\text { 2. Ratio Likuiditas Loan to Deposit Ratio (LDR) }\end{array}$ & 18,07 & 15,20 & 16,41 & 16,36 & 17,54 \\
\hline $\begin{array}{l}\text { 3. Ratio Profitabilitas } \\
\text { ROA }\end{array}$ & 1,98 & 2,25 & 2,74 & 3,11 & 2,99 \\
\hline BOPO & 71,43 & 67,0 & 67,83 & 62,52 & 65,19 \\
\hline
\end{tabular}

\section{Sumber: Data diolah}

Berdasarkan tabel diatas dapat diketahui bahwa perkembangan kinerja Bank Mandiri (Persero) Tbk, dari tahun 2007 sampai dengan 2011 dilihat dari rasio permodalan yaitu dengan rasio CAR nya berfruktuasi dari tahun ketahun yaitu pada tahun 2007 adalah sebesar 18,07\%, tahun 2008 CAR nya turun yaitu menjadi $15,20 \%$, tahun 2009 CAR nya naik menjadi $16,41 \%$, tahun 2010 turun lagi menjadi $16,36 \%$, dan tahun 2011 CAR nya naik lagi menjadi $17,54 \%$. Namun perkembangan kinerja Bank Mandiri ini tetap dikatakan baik (sehat), karena suatu bank dapat dikatakan sehat jika telah melebihi nilai CAR yang telah ditetapkan oleh Bank Indonesia yaitu $8 \%$.

Dilihat dari rasio likuiditas yaitu rasio LDR dari tahun 2007 sampai dengan tahun 2011 perkembangan kinerja Bank Mandiri mengalami peningkatan setiap tahunnya, tahun 2007 adalah sebesar 48,83\%, tahun 2008 sebesar 54,74\%, tahun 2009 sebesar 59,19\%, tahun 2010 sebesar $67,74 \%$, dan tahun 2011 adalah sebesar 74,76\%. Dan 
peningkatan nilai LDR nya tidak melebihi batas nilai yang sehat sebagai mana telah ditetapkan oleh Bank Indonesia yaitu bank yang sehat memiliki nilai maksimum $110 \%$.

Untuk rasio profitabilitas yaitu untuk ROA dan BOPO perkembangan kinerjanya juga baik (sehat) dilihat dari tahun 2007 sampai dengan tahun 2011. Dimana untuk ROA mengalami peningkatan yaitu tahun 2007 adalah sebesar 1,98\%, tahun 2008 sebesar 2,25\%, tahun 2009 sebesar 2,74\%, tahun 2010 sebesar 3,11\%, dan tahun 2011 sebesar 2,99\%. Dan untuk BOPO mengalami fluktuasi dimana pada tahun 2007 sebesar 71,43\%, tahun 2008 sebesar 67,0\%, tahun 2009 sebesar 67,83\%, tahun 2010 sebesar
62,52\%, dan tahun 2011 sebesar $65,19 \%$, akan tetapi hal tersebut tidak mempengaruhi kualitas bank karena bank yang sehat nilai BOPO dibawah $93,5 \%$, dan nilai ROA minimal $1,5 \%$, sebagaimana telah ditetapkan oleh Bank Indonesia.

\section{b. Analisis Perkembangan Kinerja Bank BRI tahun 2007 sampai dengan Tahun 2011}

Perkembangan kinerja Bank BRI (Persero) Tbk ini dapat dilihat dengan menggunakan rasio permodalan, rasio likuiditas, dan rasio profitabilitas. Untuk lebih jelas dapat dilihat perhitungannya pada tabel 2 dibawah ini:

Tabel 2

Analisis Kinerja keuangan Bank BRI Tahun 2007 sampai dengan 2011( \%)

\begin{tabular}{|l|c|c|c|c|c|}
\hline KETERANGAN & $\mathbf{2 0 0 7}$ & $\mathbf{2 0 0 8}$ & $\mathbf{2 0 0 9}$ & $\mathbf{2 0 1 0}$ & $\mathbf{2 0 1 1}$ \\
\hline 1. Ratio Permodalan (CAR) & 16,39 & 11,95 & 11,54 & 11,46 & 14,16 \\
\hline $\begin{array}{l}\text { 2. Ratio Likuiditas Loan to Deposit Ratio (LDR) } \\
\text { 3. Ratio Profitabilitas }\end{array}$ & 61,16 & 72,07 & 80,17 & 71,9 & 117,72 \\
\hline ROA & 3,82 & 3,59 & 3,12 & 3,69 & 3,99 \\
\hline BOPO & 62,10 & 63,47 & 62,80 & 55,50 & 57,14 \\
\hline
\end{tabular}

Sumber: Data diolah

Berdasarkan table diatas dapat diketahui bahwa perkembangan kinerja Bank BRI (Persero) Tbk, dari tahun 2007 sampai dengan 2011 dilihat dari rasio permodalan yaitu dengan rasio CAR bank BRI ini adalah baik (sehat) walaupun terjadi penurunan pada tahun 2008, 2009, dan 2001. karena suatu bank dapat dikatakan sehat jika telah melebihi nilai CAR yang telah ditetapkan oleh Bank Indonesia yaitu $8 \%$. Rasio CAR yang diperoleh bank BRI (Persero) Tbk pada tahun 2007 adalah sebesar 16,39\%, tahun 2008 CAR nya turun yaitu menjadi $11,95 \%$, tahun 2009 CAR nya turun menjadi $11,54 \%$, tahun 2010 turun lagi menjadi $11,46 \%$, dan tahun 2011 CAR nya naik menjadi $14,16 \%$.

Dilihat dari rasio likuiditas yaitu rasio LDR dari tahun 2007 sampai dengan tahun 2011 perkembangan kinerja Bank BRI ini juga baik (sehat), karena jika suatu bank bisa dikatakan sehat apabila nilai LDR nya tidak melebihi nilai yang telah ditetapkan oleh Bank Indonesia yaitu maksimum $110 \%$. Rasio LDR yang diperoleh oleh Bank BRI (Persero) Tbk tahun 2007 adalah sebesar $61,16 \%$, tahun 2008 
sebesar 72,07\%, tahun 2009 sebesar $80,17 \%$, tahun 2010 sebesar $71,9 \%$, dan pada tahun 2011 perkembangan kinerja bank ini (tidak baik/sehat) karena nilai LDR nya melebihi nilai yang telah ditetapkan oleh Bank Indonesia, yaitu nilai LDR nya adalah sebesar $117,72 \%$.

Rasio profitabilitas yaitu untuk ROA dan BOPO perkembangan kinerjanya juga baik (sehat) dilihat dari tahun 2007 sampai dengan tahun 2011, karena bank yang sehat nilai ROA minimal $1,5 \%$, dan BOPO dibawah 93,5\% sebagai mana telah ditetapkan oleh Bank Indonesia. Dimana untuk ROA tahun 2007 adalah sebesar 3,82\%, tahun 2008 sebesar 3,59\%, tahun 2009 sebesar 3,12\%, tahun 2010 sebesar
3,69\%, dan tahun 2011 sebesar 3,99\%. Dan untuk BOPO tahun 2007 sebesar $62,10 \%$, tahun 2008 sebesar $63,47 \%$, tahun 2009 sebesar 62,80\%, tahun 2010 sebesar 55,50\%, dan tahun 2011 sebesar $57,14 \%$.

\section{c. Analisis Perkembangan Kinerja Bank BTN tahun 2007 sampai dengan Tahun 2011}

Untuk

mengetahui

perkembangan kinerja Bank BTN (Persero) Tbk yaitu dengan menggunakan rasio permodalan, rasio likuiditas, dan rasio profitabilitas, dapat dilihat perhitungannya pada table 4.2.3 dibawah ini:

Tabel 3

Analisis Kinerja Keuangan Bank BTN Tahun 2007 sampai dengan 2011( \%)

\begin{tabular}{|l|c|c|c|c|c|}
\hline KETERANGAN & $\mathbf{2 0 0 7}$ & $\mathbf{2 0 0 8}$ & $\mathbf{2 0 0 9}$ & $\mathbf{2 0 1 0}$ & $\mathbf{2 0 1 1}$ \\
\hline 1. Ratio Permodalan (CAR) & 69,99 & 9,05 & 13,41 & 12,04 & 10,17 \\
\hline \begin{tabular}{l} 
2. Ratio Likuiditas Loan to Deposit Ratio (LDR) \\
\hline $\begin{array}{l}\text { 3. Ratio Profitabilitas } \\
\text { ROA }\end{array}$
\end{tabular} & 96,95 & 102,48 & 94,55 & 94,41 & 87,37 \\
\hline BOPO & 89,15 & 85,89 & 86,59 & 82,34 & 80,44 \\
\hline
\end{tabular}

\section{Sumber: Data diolah}

Berdasarkan table diatas dapat diketahui bahwa kondisi Bank BTN (Persero) Tbk, dari tahun 2007 sampai dengan 2011 dilihat dari rasio permodalan yaitu dengan rasio CAR bank BTN ini adalah baik (sehat) meskipun nilainya yang turun-naik setiap tahunnya, karena suatu bank dapat dikatakan sehat jika telah melebihi nilai CAR yang telah ditetapkan oleh Bank Indonesia yaitu 8\%. Rasio CAR yang diperoleh bank BTN (Persero) Tbk pada tahun 2007 adalah sebesar $69,99 \%$, tingginya nilai CAR ini disebabkan oleh besarnya tambahan modal dibandingkan tahuntahun berikutnya, tahun 2008 CAR nya turun yaitu menjadi 9,05\%, tahun 2009 CAR nya naik menjadi $13,41 \%$, tahun 2010 turun menjadi $12,04 \%$, dan tahun 2011 CAR nya juga turun menjadi $10,17 \%$.

Dilihat dari rasio likuiditas yaitu rasio LDR perkembangan kinerja Bank BTN dari tahun 2007 sampai dengan tahun 2011 juga baik (sehat) walaupun terjadi penurunan setiap tahunnya, karena ketentuan untuk LDRyang baik (sehat) adalah tidak melebihi nilai yang telah ditetapkan oleh Bank Indonesia yaitu sebesar $110 \%$. Rasio LDR yang diperoleh oleh Bank BTN (Persero) Tbk tahun 2007 adalah sebesar 96,95\%, tahun 2008 sebesar $102,48 \%$, tahun 
2009 sebesar 94,55\%, tahun 2010 sebesar 94,41\%, dan tahun 2011 sebesar $87,37 \%$.

Untuk rasio profitabilitas yaitu untuk rasio ROA tahun 2007, 2010, dan 2011 perkembangan kinerjanya baik (sehat), karena bank yang sehat nilai ROA minimum 1,5\%, pada tahun 2007 sebesar 1,64\%, tahun 2010 sebesar 1,83\%, dan tahun 2011 sebesar 1,71\%. Akan tetapi ROA tahun 2008 dan 2009 tidak sehat karena nilai ROA nya dibawah nilai yang ditetapkan oleh Bank Indonesia. Yaitu pada tauhun 2008 sebesar $1,48 \%$ dan tahun 2009 adalah sebesar 1,28\%. Dan untuk BOPO dari tahun 2007 sampai dengan tahun 2011 adalah baik (sehat), karena bank yang sehat nilai BOPO dibawah
93,5\% sebagai mana telah ditetapkan oleh Bank Indonesia. BOPO tahun 2007 sebesar $89,15 \%$, tahun 2008 turun menjadi 85,89\%, tahun 2009 naik menjadi 86,59\%, tahun 2010 turun menjadi 582,34\%, dan tahun 2011 juga turun menjadi $80,44 \%$.

\section{d. Analisis Perkembangan Kinerja Bank BNI tahun 2007 sampai dengan Tahun 2011}

Perkembangan kinerja Bank BNI (Persero) Tbk yang dilihat dengan menggunakan rasio permodalan, rasio likuiditas, dan rasio profitabilitas. Untuk lebih jelas dapat dilihat perhitungannya pada tabel 4 dibawah ini:

Tabel 4

Analisis Kinerja Keuangan Bank BNI Tahun 2007 sampai dengan 2011( \%)

\begin{tabular}{|l|c|c|c|c|c|}
\hline KETERANGAN & $\mathbf{2 0 0 7}$ & $\mathbf{2 0 0 8}$ & $\mathbf{2 0 0 9}$ & $\mathbf{2 0 1 0}$ & $\mathbf{2 0 1 1}$ \\
\hline 1. Ratio Permodalan (CAR) & 14,15 & 12,90 & 10,17 & 14,57 & 12,23 \\
\hline $\begin{array}{l}\text { 2. Ratio Likuiditas Loan to Deposit Ratio (LDR) } \\
\begin{array}{l}\text { 3. Ratio Profitabilitas } \\
\text { ROA }\end{array}\end{array}$ & 53,93 & 61,85 & 57,71 & 63,29 & 63,86 \\
\hline BOPO & 98,51 & 0,96 & 1,51 & 2,21 & 2,49 \\
\hline
\end{tabular}

\section{Sumber: Data diolah}

Berdasarkan table diatas dapat diketahui bahwa perkembangan kinerja Bank BNI (Persero) Tbk, dari tahun 2007 sampai dengan 2011 dilihat dari rasio permodalan yaitu dengan rasio CAR perkembangan kinerjanya baik (sehat), yaitu pada tahun 2007 adalah sebesar $14,15 \%$, tahun 2008 CAR nya turun yaitu menjadi $12,90 \%$, tahun 2009 CAR nya turun menjadi $10,17 \%$, tahun 2010 naik menjadi $14,57 \%$, dan tahun 2011 CAR nya turun menjadi $12,23 \%$. Rasio ini bisa dikatakan baik (sehat) karena suatu bank dapat dikatakan sehat jika telah melebihi nilai CAR yang telah ditetapkan oleh Bank Indonesia yaitu $8 \%$.

Dilihat dari rasio likuiditas yaitu rasio LDR perkembangan kinerja Bank BNI dari tahun 2007 sampai dengan tahun 2011 ini juga baik (sehat), karena jika suatu bank bisa dikatakan sehat apabila nilai LDR nya tidak melebihi nilai yang telah ditetapkan oleh Bank Indonesia yaitu sebesar $110 \%$. Rasio LDR yang diperoleh oleh Bank BNI (Persero) Tbk tahun 2007 adalah sebesar 53,93\%, tahun 2008 naik menjadi 61,85\%, tahun 2009 turun menjadi $57,71 \%$, tahun 2010 naik 
menjadi 63,29\%, dan tahun 2011 juga naik $63,86 \%$.

Untuk rasio profitabilitas yaitu untuk rasio ROA perkembangan kinerjanya pada tahun 2007, dan 2008 tidak baik (tidak sehat), karena bank yang sehat nilai ROA minimum $1,5 \%$, pada tahun 2007 sebesar $0,81 \%$, tahun 2008 sebesar $0,96 \%$, pada tahun 2009 , 2010, dan 2011 bank ini adalah baik (sehat), karena nilai ROA nya melebihi nilai yang ditetapkan oleh Bank Indonesia. Yaitu pada tauhun 2009 adalah sebesar 1,51\%, tahun 2010 adalah sebesar 2,21\%, tahun 2011 adalah sebesar 2,49\%. Dan untuk BOPO tahun 2007 dan 2008 tidak baik (tidak sehat), karena nilai BOPO melebihi standar yang telah ditetapkan oleh Bank Indonesia dimana BOPO yang sehat nilainya dibawah $93,5 \%$. BOPO tahun 2007 sebesar 98,51\%, tahun $200894,97 \%$, untuk BOPO tahun 2009, 2010, dan 2011 adalah sehat karna nilai BOPO nya dibawah standar yang telah ditetapkan Bank Indonesia. Tahun 2009 adalah sebesar 68,68\%, tahun 2010 sebesar $64,69 \%$, dan tahun 2011 sebesar $65,85 \%$.

\section{SIMPULAN DAN \\ IMPLIKASI PENELITIAN \\ Simpulan}

Berdasarkan uraian penjelasan yang terdapat pada bab sebelumnya mengenai analisis dan pembahasan hasil penelitian, maka dapat disimpulkan perkembangan kinerja masing-masing bank dilihat dari analisis rasio permodalan, rasio likuiditas, dan rasio profitabilitas masing-masing bank antara lain:

\section{PT. Bank Mandiri (Persero) Tbk.}

Perusahaan yang berdiri sejak tahun 1998 ini, dapat dilihat perkembangan kinerjanya dari tahun 2007 sampai 2011, untuk rasio permodalan yaitu CAR adalah baik (sehat) karena nilai CAR melebihi nilai yang telah ditetapkan oleh bank Indonesiayaitu sebesar 8\%. Untuk rasio likuiditas yaitu rasio LDR perkembangan kinerjanya juga baik (sehat) dimana nilai LDR nya tidak melebihi ketentuan yang telah ditetapkan Bank Indonesia yaitu dibawah $110 \%$. Dan perkembangan kinerja untuk rasio profitabilitas yaitu ROA dan BOPO juga baik (sehat) karena nilai ROA yang dihasilkan masih diatas ketentuan minimum yang ditetapkan Bank Indonesia yaitu 1,5\%, dan BOPO yang dihasilkan juga tidak melebihi ketentuan yang telah ditetapkan Bank Indonesia yaitu dibawah 93,5\%.

\section{PT. Bank Rakyat Indonesia (Persero) Tbk.}

Perkembangan kinerja bank BRI yang ditunjukkan dari tahun 2007 sampai dengan tahun 2011 yaitu untuk rasio permodalan yaitu CAR, rasio likuiditas yaitu LDR, dan rasio profitabilitas yaitu ROA dan BOPO, perkembangan kinerja ketiga rasio tersebut dinyatakan baik (sehat) karena nilai rasio yang dihasilkan tidak melebihi dan tidak kurang dari ketentuan yang telah ditetapkan Bank Indonesi, yaitu untuk CAR minimum $8 \%$, LDR dibawah 110\%, ROA minimum $1,5 \%$, dan Untuk BOPO dibawah 93,5\%. Akan tetapi untuk rasio LDR pada tahun 2011 tidak sehat karena nilai LDR nya melebihi ketentuan yang telah ditetapkan yaitu $117,72 \%$ sedangkan LDR yang sehat nilainya dibawah $110 \%$.

\section{PT. Bank Tabungan Negara (Persero) Tbk.}

Perkembangan kinerja bank BTN yang dilihat dari tahun 2007 sampai 2011 yaitu untuk rasio permodalan yaitu CAR dan rasio 
likuiditsas yaitu LDR adalah baik (sehat) karena telah memenuhi ketentuan besarnya CAR dan LDR yang dihasilkan masih diatas ketentuan minimum yaitu CAR sebesar $8 \%$, dan untuk LDR tidak melebihi ketetapan yang telah ditetapkan yaitu dibawah $110 \%$ dan untuk rasio profitabilitas yaitu ROA tahun 2007, 2010 dan 2011 dinyatakan baik (sehat) karena karena nilai yang dihasilkan lebih dari yang ditetapkan Bank Indonesia yaitu minimum $1,5 \%$ tetapi untuk tahun 2008 dan 2009 tidak baik (tidak sehat) karena nilainya dibawah nilai minimum.

\section{PT. Bank Negara Indonesia (Persero) Tbk.}

Untuk bank BNI (persero) Tbk, perkembangan kinerja dari tahun 2007 sampai dengan tahun 2011 untuk rasio permodalan yaitu CAR, rasio likuiditas yaitu LDR, dan rasio profitabilitas yaitu ROA dan BOPO dinyatakan baik (sehat) karena nilai tidak melebihi dan tidak kurang dari nilai yang telah ditetapkan oleh Bank Indonesia, yaitu untuk CAR minimum $8 \%$, LDR dibawah $110 \%$, ROA minimum $1,5 \%$ dan BOPO dibawah 93,5\%. Akan tetapi ROA tahun 2007 dan tahun 2008 dinyatakan tidak sehat karena nilai yang dihasilkan dibawah nilai yang telah ditetapkan oleh Bank Indonesia. Yaitu nilai ROA tahun 2007 dan 2008 dibawah $1,5 \%$.

\section{Implikasi Penelitian}

1. PT. Bank Mandiri (Persero) Tbk.

Bedasarkan dari analisa perkembangan kinerja bank Mandiri tersebut, maka diharapkan agar Bank Mandiri tetap mempertahankannya, dimana perkembangan kinerja Bank Mandiri ketiga rasio tersebut tergolong baik (sehat).

\section{PT. Bank Rakyat Indonesia (Persero) Tbk.}

Sama halnya dengan Bank Mandiri, Bank BRI diharapkan bisa selalu mempertahankan dan meningkatkan lagi kinerjanya persaingan antar bank untuk menjadi bank yang baik sangat kuat.

\section{PT. Bank Tabungan Negara (Persero) Tbk.}

Untuk

bank

BTN

perkembangan kinerja dilihat dari rasio permodalan, rasio likuiditas, dan profitabilitas masih banyak yang perlu diperbaiki, karena hampir setiap rasio berfluksuasi.

\section{PT. Bank Negara Indonesia (Persero) Tbk.}

Untuk bank BNI perkembangan kinerja yang dilihat dari rasio permodalan, rasio likuiditas, dan profitabilitas agar diperbaiki lagi atau ditingkatkan lagi karena hampir setiap tahun terjadi fluktuasi dan hanya pada ROA yang terjadi peningkatan setiap tahunnya.

\section{DAFTAR PUSTAKA}

$\begin{array}{ccr}\text { Badan Pengawas } & \text { Pasar } & \text { Modal } \\ \text { Bekerjasama } & \text { dengan } & \text { Japan } \\ \text { Internasional } & \text { Coorparation } \\ \text { Agency, 2003 } & & \end{array}$

Direktori Perbankan Indonesia,20068, September 2007.

Hadi Wahyono, (2001) Komparasi Kinerja Perusahaan Bank di BEI, Jurnal Riset Ekonomi dan manajemen.

Herman Darmawi, (2000). Diktat Bank dan Lembaga Keuangan, Fakultas Universitas Andalas.

Herry, (2009). Teori Akuntansi, PT Raja Grafindo Persada, Jakarta

IAI, (2008). Standar Akuntansi Keuangan per 1 September 2007, 
Cetakan kedua, Salemba Empat, Jakarta.

Irham Fahmi, (2011). Analisis Laporan Keuangan, Bandung: Alfabeta.

Kasmir, (2002). Dasar-dasar Perbankan, Jakarta: PT Raja Grafindo Persada.

Kasmir, (2008). Bank dan Lembaga Keuangan Lainnya, Jakarta: PT Raja Grafindo Persada.

Kasmir. (2008). Manajemen Perbankan. Edisi Revisi 2008. PT Raja Grafindo Persada, Jakarta.

Lukman Dendawijaya. (2009). Manajemen Perbankan. Ghalia Indonesia, Jakarta.

Rivai, Veithzal dan Andra Permata Veithzal. (2006). Credit Management Handbook : Teori, Konsep, Prosedur, dan Aplikasi Panduan Praktis Mahasiswa, Bankir, dan Nasabah. PT Raja Grafindo Persada, Jakarta.

Riyadi, Slamet. (2006). Banking Asset and Liability Managemen, Edisi Ketiga, Fakultas Ekonomi Universitas Indonesia, Jakarta.

Sofyan, Syafri Harahap, (2004). Analisis Kritis Atas Laporan Keuangan, Edisi 1 Cetakan 4, Pt. Raja Grafindo Persada, Jakarta.

Statistik Perbankan Indonesia, Vol. 5 No. 5, April 2007.

Sugiyarsono, Wionarni. (2005). Manajaemen Keuangan. Media Pressido, Jakarta.

Sugiyono, (2006), Metode Penelitian Bisnis, Edisi Kesembilan, Penerbit Alfabeta, Bandung.

Tandalilin, Eduardus. (2001). Analisis Investasi dan Manajemen Portofolio. Edisi Pertama. Penerbit BPFE-Yogyakarta.

http://www.bei.co.id http://www.bankmandiri.co.id http://www.bni.co.id http://www.bri.co.id http://www.btn.co.id http://www.idx.co.id 